Journal of Applied Biology \& Biotechnology Vol. 5 (01), pp. 059-065, Jan-Feb, 2017

Available online at http://www.jabonline.in

DOI: $10.7324 / \mathrm{JABB} .2017 .50110$

(c) $\mathrm{BY}-\mathrm{NC}-\mathrm{SA}$

\title{
DNP induced oxidative stress on blood components ameliorated by Pyrrole derivative of Tinospora cordifolia.
}

\author{
K. C. Rashmi, H. S. Aparna* \\ Department of Studies in Biotechnology, University of Mysore, Mysore-570 006, India.
}

\begin{tabular}{|c|c|}
\hline ARTICLE INFO & ABSTRACT \\
\hline $\begin{array}{l}\text { Article history: } \\
\text { Received on: } 10 / 09 / 2016 \\
\text { Revised on: } 09 / 10 / 2016 \\
\text { Accepted on: } 22 / 10 / 2016 \\
\text { Available online: } 20 / 01 / 2017\end{array}$ & $\begin{array}{l}\text { The intoxications and deaths caused by } 2 \text {, 4-dinitrophenol (DNP) exposure through drugs, food supplements have } \\
\text { been frequently reported and no specific treatment has been implemented to the toxic effects of DNP in adults and } \\
\text { children. In this study, the purified compound (TCCP), a bioactive molecule from Tinospora cordifolia exhibited } \\
\text { radical scavenging activities. Hence, we investigated the in vitro effect of TCCP on oxidative stress induced by } \\
\text { DNP. Blood samples from healthy donors were treated with DNP }(100 \mu \mathrm{M} / \mathrm{ml}) \text { for } 2 \mathrm{~h} \text {. The DNP induced oxidative }\end{array}$ \\
\hline $\begin{array}{l}\text { Key words: } \\
\text { Tinospora cordifolia, } \\
\text { Pyrrole, DNP, oxidative } \\
\text { stress. }\end{array}$ & $\begin{array}{l}\text { damage and effect of TCCP pre-treatment were determined by assessing the serum levels of cytoplasmic, } \\
\text { lysosomal and oxidative stress markers. TCCP effectively inhibited DNP-induced oxidative stress on blood } \\
\text { components, which was evidenced by the levels of endogenously generated reactive oxygen species and hydrogen } \\
\text { peroxide. In addition, the depletion of GSH (reduced glutathione) content in DNP-treated cells was prevented by } \\
\text { TCCP. Also, experimental results reflected the decreased expression of inflammation marker such as lipid } \\
\text { peroxidase, catalase, LDH (lactate dehydrogenase), and phosphatase levels in cells with TCCP pre incubated DNP } \\
\text { treated group. Therefore, these studies suggest the use of TCCP as an antioxidant and anti-inflammatory agent. }\end{array}$ \\
\hline
\end{tabular}

\section{INTRODUCTION}

2, 4-Dinitrophenol (DNP) has historically been used in the manufacture of food coloring, clothing dyes, explosives, agricultural herbicides, insecticides and fungicides [1, 2]. The compound is known to uncouple mitochondrial oxidative phosphorylation and was used as an antiobesity agent early in the past century. Because of its potentially fatal adverse effects, including hyperthermia, cataract, agranulocytosis, hepatotoxicity, nephrotoxicity and cardiotoxicity, the compound was subsequently banned by the United States Food and Drug Administration [3]. Banning DNP sale for human consumption protects the general public but DNP is still sold mostly via internet sales. DNP is purchased and used by determined users who are not dissuaded from experimenting with DNP based on health threats. However, the popularity of DNP as a slimming aid has resurfaced again in recent years [4]. DNP is used by bodybuilders and extreme dieters for its fat burning properties through inhibiting efficient energy

\footnotetext{
* Corresponding Author
}

Dr. H. S. Aparna, Department of Studies in Biotechnology, University of Mysore, Mysore- 570 006, Karnataka, India. Tel: 91 - 821 - 2419482 (O); Fax: 91 -821 -2419363(O); Email Id: hsa.uom @ gmail.com
(ATP) production in cells [5]. Through uncoupling mitochondrial oxidative phosphorylation by facilitating proton transport across the mitochondrial membrane, DNP leads to rapid consumption of energy without generating ATP and consequently, to increased fat metabolism. DNP is sold in different names like dinosan, dnoc, solfo Black, nitrophen, aldifen and chemox. Some internet sites have DNP available in bulk quantities, allowing users to purchase kilograms of DNP powder or hundreds/ thousands of DNP-containing tablets [6]. Water contamination due to spillage of DNP during transportation or from factories and industries leads to toxic injuries on exposure [7]. Moreover, adults and children from farming communities are vulnerable to toxic injuries from the chemical DNP present in pesticides and insecticides [8]. The classic phenomena noticed by overdose of phenol-based product, DNP is a combination of hyperthermia, tachycardia, diaphoresis and tachypnoea [9]. In animal studies, DNP has been shown to be teratogenic, mutagenic and carcinogenic; including developmental and reproductive toxicity has been reported [10]. Owing to acute DNP toxicity and preceding death, the patient is often profoundly hyperthermic associated with methaemoglobinaemia, a disorder with higher level of methemoglobin [11]. Methemoglobin is a form of abnormal hemoglobin that contains iron in ferric $\left[\mathrm{Fe}^{3+}\right]$ form rather than the usual ferrous $\left[\mathrm{Fe}^{2+}\right]$ form. 
Ferric $\left[\mathrm{Fe}^{3+}\right]$ iron has a decreased ability to bind oxygen but the ferrous iron has an increased affinity for bound oxygen. The binding of oxygen to methemoglobin results in an increased affinity of oxygen to the three other heme sites (that are still ferrous) within the same tetrameric hemoglobin unit. This leads to an overall reduced ability of the red blood cell to release oxygen to tissues [12].

Tinospora cordifolia from Menispermaceae family is one of the frequently used medicinal plants in Indian ayurvedic medicine as a tonic, vitalizer and as a remedy for various metabolic disorders [13]. The chemical constituents reported from this shrub belong to different classes, such as diterpenoid lactones, alkaloids, phenolics, glycosides, sesquiterpenoid, steroids, aliphatic compounds and polysaccharides [14]. Potential medicinal properties revealed by researchers include anti-allergic, anti-stress, anti-diabetic, antipyretic, antispasmodic, anti-inflammatory, antiarthritic, antioxidant, anti-leprotic, antimalarial, anti-arthritic, antispasmodic, hepato-protective, immuno-modulatory and antineoplastic activities $[15,16]$.

Individual parts or whole $T$. cordifolia plant have been reported to improve the immune system and anti-oxidant properties in various in vitro and in vivo models [17]. Previously, the anti-inflammatory effect of $T$. cordifolia was seen on paw edema model in rats induced by carrageenan [18]. Several reports indicate anti-inflammatory activity of the decoction [19], alcohol extract [20], water extract of the stem of $T$. cordifolia [21, 22] and T. cordifolia extract has been proved to possess protective effect against asthmatic inflammation and oxidative stress[23]. Epicatechin from $T$. cordifolia stem extract showed antioxidant property [24].

Number of studies has been documented on biological activities of $T$. cordfolia against various diseases, there is a paucity of information, especially against DNP induced oxidative stress with reference to lipid peroxidation and other antioxidant marker's status. As there is no specific antidote or specific management for individuals with DNP-related toxicity, the present study was conducted to evaluate the protective effect of the purified compound, a pyrrole derivative (TCCP) from $T$. cordifolia plant against the oxidative stress induced by DNP using blood components.

\section{MATERIALS AND METHODS}

\subsection{Plant Material}

\subsubsection{Extraction and Isolation}

Leaves of Tinospora cordifolia (Willd.) Miers from the family Menispermaceae, were collected from Mysuru, India. The plant was identified and authenticated by taxonomist Dr. Sudarshan, department of Botany, University of Mysore, Mysuru.

Shade dried and powdered leaves of the plant were soxhlet extracted with non-polar to polar solvent system. Since the bioactivity and the yield $(1.6 \mathrm{~g} / 30 \mathrm{~g})$ obtained from butanolic fraction were high it was freed from solvent under reduced pressure to a thick green mass and used for further purification.

\subsection{Column chromatography}

The column chromatography (Length: $35 \mathrm{~cm}$; Bore: $2 \mathrm{~cm}$ ) was performed using 60-120 mesh silica gel to elute out individual components from the crude butanol extract. The mixture of ethylacetate and methanol $(2: 1, \mathrm{v} / \mathrm{v})$ showed best result as eluting solvent mixture. The column was rinsed with the same solvent mixture and completely dried before use. The column was filled $3 / 4$ th with solvent mixture and the silica gel was packed approximately $2 / 3 \mathrm{rd}$ of the column length with simultaneous draining of the solvent to aid proper packing. The packing was performed after activating the silica gel at $100{ }^{\circ} \mathrm{C}$ for $1 \mathrm{~h}$ and gently poured on the top of the column with constant tapping to avoid air bubbles and cracks after mixing with ethylacetate and methanol. The column was run with crude butanol extract (200 $\mathrm{mg}$ ) mixed with $2 \mathrm{~g}$ of activated silica gel. The flow rate was maintained at $1 \mathrm{~mL}$ per min and the fractions collected were tested by HPTLC (High performance thin layer chromatography) using the solvent system toulene, ethylacetate, chloroform and acetic acid $(6: 2: 5: 2, v / v)$ for single spot. Fractions with identical spots and $\mathrm{R}_{\mathrm{f}}$ value were pooled together and named as TCCP, preceded for further analysis.

\subsection{Chemicals}

2, 4-Dinitrophenol (DNP), dichlorodihydrofluorescein diacetate (DCFDA), HEPES [4-(2-hydroxyethyl)-1piperazineethanesulfonic acid], homovanillic acid (HVA), thiobarbituric acid (TBA), 1, 1, 3, 3-tetramethoxypropane (TMP), quercetin were from Sigma Chemical Co. (St. Louis, MO, USA). All other chemicals were of analytical grade reagents.

\subsection{Evaluation of free radical scavenging activity}

The free radical scavenging activity of TCCP was performed using DPPH and ABTS radical cation decolorization assay methods and IC50 was determined [25, 26].

\subsection{Experimental design}

Experiment was designed according to the method followed by Santhosh et al [27]. Venous blood from healthy, nonsmoking human volunteers was drawn with informed consent according to the Institutional human ethical committee guidelines (IHEC-UOM No. 59/Ph.D/2011-12), University of Mysore, Mysore. Blood samples were collected in empty tubes and categorized into different groups: Group I- Control blood, Group II- DNP alone $(100 \mu \mathrm{M} / \mathrm{ml})$, Group III- DNP pre-incubated with TCCP for $10 \mathrm{~min}$ at $37^{\circ} \mathrm{C}(1: 1$ ratio, w/w $)$ and Group $I V$ - TCCP alone $(100 \mu \mathrm{M} / \mathrm{ml})$. The tubes were incubated at $37^{\circ} \mathrm{C}$ for $2 \mathrm{~h}$ and the serum samples were then separated from the cells by centrifugation at $3,000 \mathrm{rpm}$ for $15 \mathrm{~min}$ and used to perform further experiments.

\subsection{Determination of ROS levels}

The endogenous reactive oxygen species (ROS) levels were measured as described by Driver et al [28] with slight modifications. Serum samples $(10 \mu \mathrm{l})$ from each group were 
incubated with Locke's solution $(154 \mathrm{mM} \mathrm{NaCl}, 5.6 \mathrm{mM} \mathrm{KCl}$, $3.6 \mathrm{mM} \mathrm{NaHCO}{ }_{3}, 5.0 \mathrm{mM}$ HEPES, $2.0 \mathrm{mM} \mathrm{CaCl}_{2}, 10 \mathrm{mM}$ glucose, $\mathrm{pH7.4)}$ for 30min at room temperature followed by the addition of $10 \mu \mathrm{M}$ of DCFDA. The reaction mixture was incubated at $37^{\circ} \mathrm{C}$ for $30 \mathrm{~min}$ and the resulting fluorescence was measured using a Varioskan multimode plate reader (Thermo Scientific, USA) with excitation and emission wavelengths of 480 and 530nm, respectively. ROS levels were quantified from a dichlorofluorescein (DCF) standard curve and expressed as pmol DCF formed $/ \mathrm{min} / \mathrm{mg}$ protein.

\subsection{Determination of endogenously generated $\mathrm{H}_{2} \mathrm{O}_{2}$}

The rate of $\mathrm{H}_{2} \mathrm{O}_{2}$ production was estimated by measuring the increase in fluorescence due to oxidation of HVA (a specific hydrogen peroxide sensitive dye) by $\mathrm{H}_{2} \mathrm{O}_{2}$ according to the method outlined by Barja et al [29]. The serum sample $(0.2 \mathrm{mg})$ was added to the reaction mixture containing $200 \mu \mathrm{l}$ HEPES buffered saline

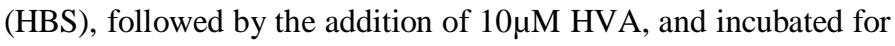
$30 \mathrm{~min}$ at $37^{\circ} \mathrm{C}$. Samples were excited at $312 \mathrm{~nm}$ and the resulting fluorescence was measured at $420 \mathrm{~nm}$.

\subsection{Lipid peroxidation}

Induction of oxidative damage was ascertained by measuring the extent of lipid peroxidation in the serum sample by estimating thiobarbituric acid reactive substances (TBARS) according to the method of Ohkawa et al [30]. An aliquot of the sample (1.0mg protein) was added to tubes containing $1.5 \mathrm{ml}$ of


thiobarbituric acid $(0.8 \% \mathrm{w} / \mathrm{v})$. The mixture was heated in a boiling water bath for $45 \mathrm{~min}$. The adducts formed were extracted into 1-butanol $(3 \mathrm{ml})$ and the TBARS formed was read at $532 \mathrm{~nm}$ (Beckman Du 730 life science UV-Visible spectrophotometer, Germany) and quantified using TMP as the standard.

\subsection{Determination of GSH}

The GSH levels were assessed fluorimetrically as described by Chandrashekar et al [31], with minor modifications. Briefly, serum samples $(0.1 \mathrm{mg}$ protein) were added to $1 \mathrm{ml}$ formic acid $(0.1 \mathrm{M})$ and centrifuged for $10 \mathrm{~min}$ at $10,000 \mathrm{~g}$. An aliquot of the supernatant was added to sodium phosphate buffer $(0.1 \mathrm{M}, \mathrm{pH}$ 8.0, 5mM EDTA) containing buffered formaldehyde (1:4 v/v, $0.1 \mathrm{M}$ formaldehyde: $0.1 \mathrm{M} \mathrm{Na} \mathrm{NaO}_{2}$ ) and $0.1 \mathrm{ml}$ of o-phthaldialdehyde. The mixture was incubated for $45 \mathrm{~min}$ at $37^{\circ} \mathrm{C}$ and the fluorescence was measured at excitation and emission wavelengths of 345 and $425 \mathrm{~nm}$. The concentration of GSH was calculated using the standard curve and the values were expressed as $\mathrm{mM}$ $\mathrm{GSH} / \mathrm{mg}$ protein.

\subsection{Activity of antioxidant enzymes 3.0.1. Catalase \& Lactate dehydrogenase ( $\mathrm{LDH})$}

Catalase activity was determined by measuring the rate of hydrolysis of $\mathrm{H}_{2} \mathrm{O}_{2}$ at 240nm by the method described by Aeibi et al[32]. To the reaction mixture $(1 \mathrm{ml})$ containing $\mathrm{H}_{2} \mathrm{O}_{2}(8.8 \mathrm{mM})$ in sodium phosphate buffer $(0.1 \mathrm{M}, \mathrm{pH} 7.0)$, an aliquot of serum samples $(0.05 \mathrm{mg}$ protein) was added independently. The decrease in absorbance was monitored for $3 \mathrm{~min}$ and the activity was expressed as $\mu \mathrm{mol} \mathrm{H}_{2} \mathrm{O}_{2}$ decomposed/min/ $\mathrm{mg}$ protein (€$43.6 / \mathrm{mM} / \mathrm{cm})$

The serum LDH levels were measured spectrophotometrically by a standard enzymatic method using commercial diagnostic kit (LDH kit, Agappe diagnostics, India) at $340 \mathrm{~nm}$ and expressed as activity/min mg protein.

\subsubsection{Acid (ACP) \& Alkaline phosphatase (ALP)}

Acid phosphates enzyme activity was measured by the method as discussed in Tenniswood et al [33], using pNPP as substrate with slight modification. The reaction was initiated by mixing $1 \mathrm{ml}$ of substrate solution $(20 \mathrm{mM}$ pNPP in $0.1 \mathrm{M}$ acetate buffer, pH3.8) with serum (0.2mg). After $15 \mathrm{~min}$ of incubation at $30^{\circ} \mathrm{C}$, the reaction was stopped by adding $3 \mathrm{ml}, 1 \mathrm{M} \mathrm{NaOH}$, a blank without addition of enzyme must be run. Product formed $p$ Nitrophenolate anion (PNP) was measured at 400nm (Beckman Du 730 life science UV-Visible spectrophotometer, Germany), against blank. Activity was expressed as amount of enzyme that converts $p$-Nitrophenylphosphate (PNPP) to $\mathrm{PNP} / \mathrm{min} / \mathrm{mg}$ protein.

Alkaline phosphates enzyme activity was measured by diethanolamine [N, N-Bis (2-hydroxyethyl) amine] method with slight modifications [34]. In a reaction mixture of $3 \mathrm{ml}, 2.9 \mathrm{ml}$ of $1 \mathrm{M}$ diethanolamine of $\mathrm{pH} 9.8$ containing $0.50 \mathrm{mM}$ magnesium chloride buffer was mixed with $50 \mu 1,0.67 \mathrm{M}$ of substrate (PNPP) and equilibrated for $5 \mathrm{~min}$ at $37^{\circ} \mathrm{C}$. $50 \mu \mathrm{l}$ of $0.1 \mathrm{mg}$ of serum was added, immediately it was mixed by inversion and increase in absorbance was recorded for $5 \mathrm{~min}$ at 410nm. Difference in A410 was obtained and enzyme activity was expressed as amount of enzyme that converts $p$-Nitrophenylphosphate (PNPP) to $p$ $\mathrm{Nitrophenol} / \mathrm{min} / \mathrm{mg}$ protein.

\subsection{Protein estimation}

The protein concentration was determined by the Lowry's method [35] using BSA as standard, at 660nm.

\subsection{Statistical Analysis}

The experiments were carried out in triplicates $(n=3)$ and analyzed by applying one way analysis of variance (ANOVA). Values are expressed as mean \pm SEM. Statistical significance between control and treated blood samples were determined by Dunnett's test. For all tests, $P<0.01$ was considered statistically extremely significant, $P<0.05$ significant and non significant when $P>0.5$.

\section{RESULTS AND DISCUSSION}

\subsection{Effect of TCCP on radical scavenging activity and endogenous antioxidant markers- $\mathrm{ROS}$ and $\mathrm{H}_{2} \mathrm{O}_{2}$}

For many years, a large number of natural compounds of varied structures derived from medicinal plants have been suggested as the major source of anti-oxidants and are capable of exerting protective effects against oxidants and inflammation in 
biological systems. T. cordifolia has been traditionally used as herbal medicine for the treatment of various illnesses that involve inflammation and oxidative stress. It is well known that the antiinflammatory and antioxidant activities are closely interrelated. The free radical scavenging activity of TCCP was found to increase with increase in concentration. The IC50 values assessed by DPPH and ABTS methods were $100 \mu \mathrm{M}$ and $89 \mu \mathrm{M}$ respectively.

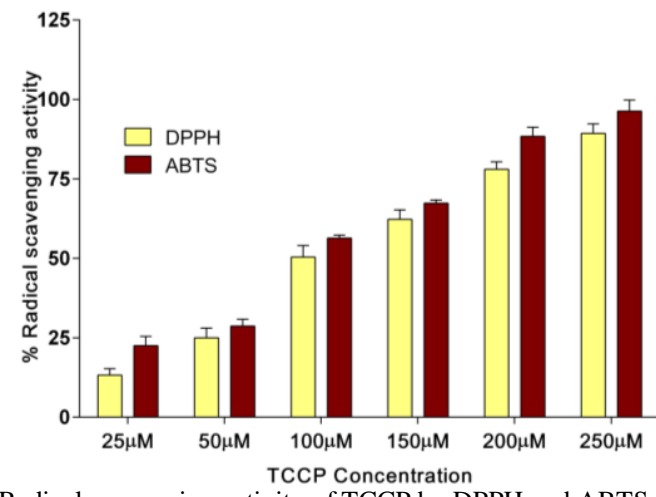

Fig. 1: Radical scavenging activity of TCCP by DPPH and ABTS methods.

Generally in RBCs, at normal physiological conditions, the reaction of heme with peripheral environment is controlled since it resides inside the pockets of heme proteins. However, during oxidative stress by pro inflammatory chemicals like DNP, hemoglobin tends to release its heme prosthetic groups. For this reason, the free heme produced becomes highly toxic to the cells by creating free radicals due to reduction of ferric ( +3 ion) form to ferrous $(+2)$ form which take part in Fenton reaction contained within its protoporphyrin IX ring. Within the RBC, deoxygenation of haemoglobin $(\mathrm{Hb})$ is followed by the generation of $\mathrm{O}^{-2}$. This reaction occurs to a lesser extent in normal $\mathrm{RBC}$. But during stress, much more $\mathrm{O}^{-2}$ is generated leading to denaturation, precipitation, haemichrome formation and ROS production [36, 37]. Aqueous extract of $T$. cordifolia inhibited fenton reaction in a dose dependent fashion with an IC50 value of $700 \mathrm{mg} / \mathrm{ml}$ [38].

A significant enhancement in the levels of ROS (137\%) compared to control $(\mathrm{p}<0.01)$ was evident in the serum when the whole blood was incubated with DNP $(100 \mu \mathrm{g} / \mathrm{ml}$ blood $)$. However, the levels of ROS were significantly reduced by $38 \%$ when DNP was preincubated with TCCP and 50\% in TCCP-alone group (Fig. 2a). On the other hand, a slight elevation in the levels of $\mathrm{H}_{2} \mathrm{O}_{2}$ was observed in the DNP-treated group. In case of group III, in which DNP was preincubated with TCCP, the levels of $\mathrm{H}_{2} \mathrm{O}_{2}$ were significantly reduced by $62 \%$ compared to control and in the case of TCCP alone, TCCP reduced the endogenous $\mathrm{H}_{2} \mathrm{O}_{2}$ levels by $68 \%$ compared to the control group (Fig. 2b).

It is known that iron catalyzes the formation of ROS and thus alters the cellular redox state. Another plausible cause for oxidative stress in RBC may be the high concentrations of iron and iron-containing compounds, such as heme and $\mathrm{Hb}$, in the plasma owing to haemolysis and blood transfusions [39].

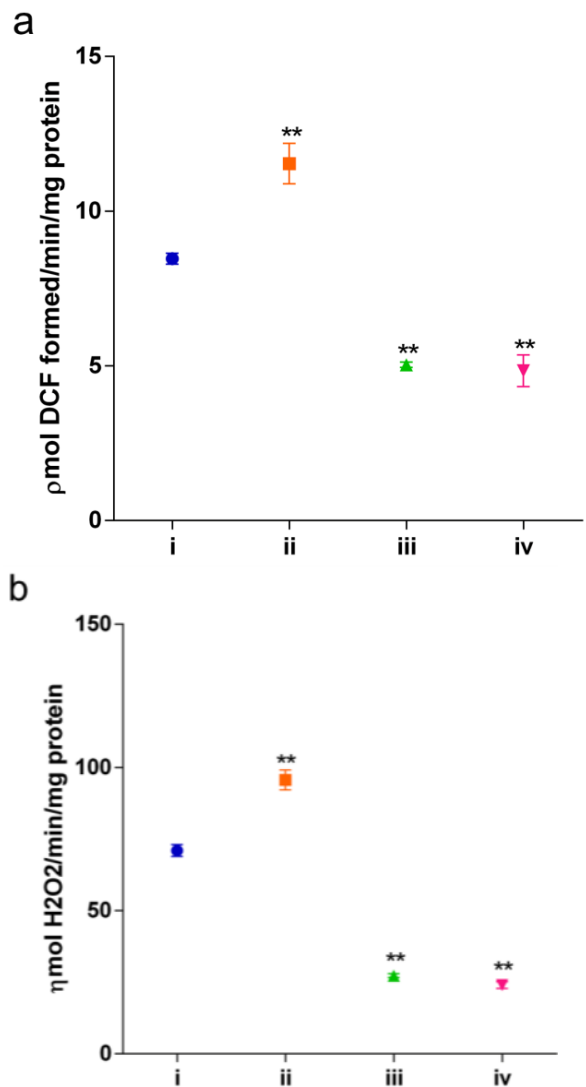

Fig. 2: Effect of TCCP on DNP- induced ROS generation and $\mathrm{H}_{2} \mathrm{O}_{2}$ levels in blood samples. i. Control, ii. Blood treated with DNP, iii. Blood treated with DNP that was pre- incubated with TCCP and iv. Blood treated with TCCP alone. Values are expressed as mean \pm SEM of three replicate analyses. ${ }^{* *} \mathrm{p}<0.01$ considered significantly different compared to control.

Exposure of RBCs, platelets and polymorphonuclear leukocytes (PMN) to iron or heme increases their ROS level. The chronic oxidative stress of RBC, PMN and platelets in DNP treated blood renders them more susceptible to endogenous ROS mediated damage. Oxidative stress triggers eryptosis which outlines cell shrinkage, membrane blebbing and phospholipid damage of the cell membrane leading to phosphatidylserine translocation to the erythrocyte surface [40]. Thus, the free radicals generated affects the neighboring cellular components by peroxidation of unsaturated fatty acids in membranes, protein degradation and DNA fragmentation [41]. Several groups have suggested that molecules, which stimulate formation of ROS, can trigger apoptosis [42-44]. The exact mechanisms involved in cell death induced by ROS are not fully understood, and the protective effect mediated by some antioxidants remains controversial. The results in the present study show that pretreatment with TCCP substantially reduced ROS and $\mathrm{H}_{2} \mathrm{O}_{2}$ induced by DNP compared to DNP alone treated RBCs.

\subsection{Effect of TCCP on intracellular lipid peroxidation and GSH status}

Lipid peroxidation is considered to be the key event that indicates marked oxidative stress. Lipid peroxidation refers to the oxidative degradation of lipids. Assessing the end product of lipid 
Peroxidation i. e., malondialdehyde (MDA) is a convenient tool for sensitive detection of oxidative damage. MDA, together with 4-hydroxynonenal (4-HNE), is a natural bi-product of lipid peroxidation and its quantification is generally used as marker for lipid peroxidation. One of the major endogenous antioxidant produced by the cells is GSH, participating directly in the neutralization of free radicals and reactive oxygen compounds, as well as maintaining exogenous antioxidants such as vitamins $\mathrm{C}$ and E in their reduced (active) forms. Data from this study clearly indicated that TCCP could inhibit lipid peroxidation and elevate GSH content in DNP treated RBCs. On the other hand, DNP treated RBCs showed elevated lipid peroxidation and drastic depletion in GSH content. Likewise, oral administration of aqueous extract of the roots from $T$. cordifolia resulted in a significant reduction in thiobarbituric acid reactive substances (TBARS) and an increase in GSH, catalase and SOD in alloxan diabetic rats [45].


Fig. 3: Effect of TCCP lipid peroxidation and GSH in blood samples treated with DNP. i. Control, ii. Blood treated with DNP, iii. Blood treated with DNP that was pre- incubated with TCCP and iv. Blood treated with TCCP alone. Values are expressed as mean \pm SEM of three replicate analyses. $\mathrm{P}>0.05=\mathrm{ns}$ (not significant), ${ }^{* *} \mathrm{p}<0.01$ considered significantly different from control.

In the present study the extent of lipid peroxidation was measured in terms of MDA levels and a considerable increase (1:9) was observed in the DNP treated group compared to control. Interestingly, in the pre-incubation group did not show any significant alterations but complete normalization of lipid peroxidation was observed in the TCCP-alone group (Fig. 3a). In the DNP-treated group, there was a drastic decline $(66 \%)$ in serum GSH level compared to control. The decreased levels of GSH reverted to normality by $34 \%$ when pre-incubated with TCCP $(1: 1$ ratio, w/w). In addition, a slight decrease in the endogenous levels of GSH was seen in the TCCP-treated group (Fig. 3b).

\subsection{Effect of TCCP on enzyme levels- Catalase, LDH, ACP and ALP}

On the other hand, a dramatic elevation in the activity of catalase was seen in the TCCP- treated group (18.5-fold). In contrast, TCCP was able to restore the activity by $40 \%$ when preincubated with DNP. No significant alteration in enzyme activity of catalase was observed in group IV, TCCP alone (Fig. $4 a)$.

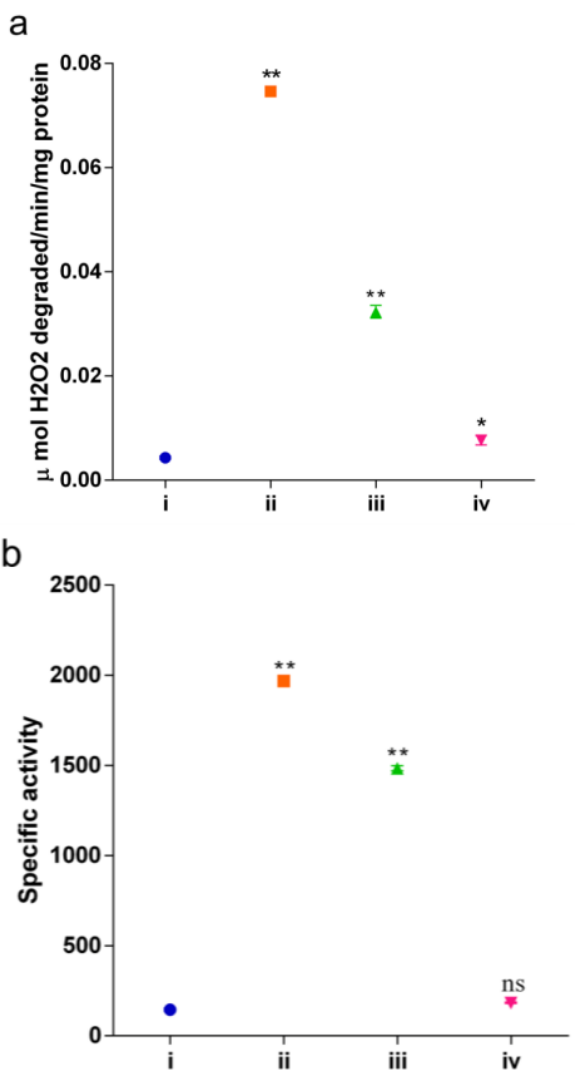

Fig. 4: Effect of TCCP on catalase activity and LDH level in DNP treated blood samples. i. Control, ii. Blood treated with DNP, iii. Blood treated with DNP that was pre- incubated with TCCP and iv. Blood treated with TCCP alone. Values are expressed as mean \pm SEM of three replicate analyses. P > $0.05=\mathrm{ns}$ (not significant), $*{ }^{*} \mathrm{p}<0.01, * \mathrm{p}<0.05$ considered significantly different compared to control.

Similarly, there was a robust elevation of LDH (Fig. 4b), ACP (Fig. 5a) and ALP activities (Fig. 5b) in the DNP treated groups. TCCP exhibited significant protective effects by diminishing LDH, ACP and ALP levels by $25 \%, 46 \%$ and $24 \%$, respectively, compared to the DNP-treated group. TCCP alone did not show any significant alterations in enzymatic activities.

There was an increase in level of both catalase and LDH in DNP treated serum due to erythrocyte damage. Catalase is an intracellular, peroxisomal and antioxidant enzyme that degrades hydrogen peroxide in to water and oxygen. It is possible that intracellular catalase may be released outside of cells, if the cells 
are injured and further stimulate neighboring cells to produce COX-2 and iNOS. The root extract of $T$. cordifolia has been reported to decrease the concentration of glycosylated hemoglobin, plasma thiobarbituric acid reactive substances, GSH, SOD and catalase activity in heart and brain of diabetic rats [46, 47]. LDH is abundant in RBCs and acts as a marker for hemolysis. Reports available on root extract of $T$. cordifolia that lowers hepatic glucose-6-phosphatase and serum acid phosphatase, alkaline phosphatase, and LDH in diabetic rats [45]. In the same way, the current results define the low level of catalase and LDH in TCCP pre incubated DNP treated serum.

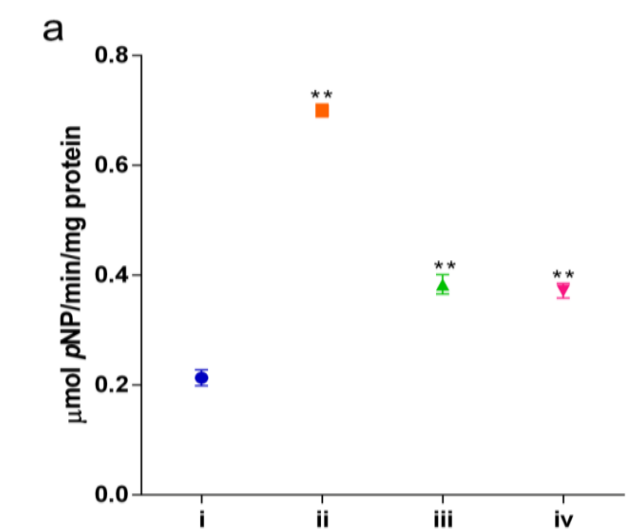

b



Fig. 5: Effect of TCCP on the levels of phosphotases (ACP and ALP) in blood samples treated with DNP. i. Control, ii. Blood treated with DNP, iii. Blood treated with DNP that was pre- incubated with TCCP and iv. Blood treated with TCCP alone. Values are expressed as mean \pm SEM of three replicate analyses $\mathrm{P}>0.05=\mathrm{ns}$ (not significant), ${ }^{* *} \mathrm{p}<0.01$ considered significantly different compared to control.

The induction of the enzymatic and non-enzymatic defensive mechanism on exposure to DNP could be an adaptive or a counteractive response that enables the cells to overcome the damage. From a previous clinical report, patient with symptoms of tachypnea and hyperthermia post consumption of DNP also showed increased LDH concentration $(768 \mathrm{U} / \mathrm{L})$. The increase in serum LDH is an indirect evidence of hemolysis [2].

The decreased level of tissue enzymes, i.e., SOD, catalase and increased level of aspartate aminotransferase (AST), alanine aminotransferase (ALT), alkaline phosphatase (ALP), and acid phosphatase (ACP) were observed in mice treated with lead. Oral administration of aqueous stem extract and aqueous leaves extract from T.cordifolia along with the lead nitrate $(5 \mathrm{mg} / \mathrm{kg}$ body weight, i.p. for 30 days) increased the activities of SOD and CAT and decreased the levels of AST, ALT, ALP, and ACP enzymes in mice [48]. Correspondingly, our results demonstrate the protective efficacy of pyrrole derivative against DNP-induced oxidative damage by stabilizing and reducing the levels of ACP and ALP in blood components.

\section{CONCLUSION}

In summary, the current study demonstrates the perturbances in blood components due to enhanced oxidative stress induced by DNP. The study also clearly demonstrates the efficacy of purified compound TCCP from $T$. cordifolia in neutralizing DNP induced oxidative stress in blood components. However, the molecular mechanism that is responsible for its protective activity of TCCP on blood components remains to be determined.

\section{ACKNOWLEDGEMENT}

Financial support and sponsorship: Authors thank the Institute of Excellence, (UOM/IOE/Research/1/2010-11) University of Mysore, Mysuru for financial support.

Conflict of Interests: There are no conflicts of interest.

\section{REFERENCES}

1. Yen M, Ewald MB. Toxicity of weight loss agents. Journal of medical toxicology. 2012;8:145-152.

2. Lee HCH, Law CY, Chen ML, Lam YH, Chan AYW, Mak TWL. 2, 4-Dinitrophenol: A threat to Chinese body-conscious groups. Journal of the Chinese Medical Association. 2014;77:443-445.

3. Colman E. Dinitrophenol and obesity: an early twentieth-century regulatory dilemma. Regulatory Toxicology and Pharmacology. 2007;48:115-117.

4. Petróczi A, Ocampo JAV, Shah I, Jenkinson C, New R, James RA, et al. Russian roulette with unlicensed fat-burner drug 2, 4dinitrophenol (DNP): evidence from a multidisciplinary study of the internet, bodybuilding supplements and DNP users. Substance abuse treatment, prevention, and policy. 2015 Oct 14;10:39. doi: 10.1186/s13011-015-0034-1.

5. Tewari A, Ali A, O'Donnell A, Butt M. Weight loss and 2, 4dinitrophenol poisoning. British Journal of Anaesthesia. 2009; 102: 566-567.

6. Grundlingh J, Dargan PI, El-Zanfaly M, Wood DM. 2, 4dinitrophenol (DNP): a weight loss agent with significant acute toxicity and risk of death. Journal of medical toxicology. 2011;7:205212.

7. Jiukun J, Zhihua Y, Weidong H, Jiezan W. 2, 4-dinitrophenol poisoning caused by non-oral exposure. Toxicology and industrial health. 2010:0748233710387004.

8. Macnab AJ, Fielden SJ. Successful treatment of dinitrophenol poisoning in a child. Pediatric emergency care. 1998;14:136-138.

9. Bartlett J, Brunner M, Gough K. Deliberate poisoning with dinitrophenol (DNP): an unlicensed weight loss pill. Emergency medicine journal. 2010;27:159-160.

10. Takahashi M, Sunaga M, Hirata-Koizumi M, Hirose A, Kamata E, Ema M. Reproductive and developmental toxicity screening study of 2, 4-dinitrophenol in rats. Environmental toxicology. 2009;24:74-81. 
11. Hsiao AL, Santucci KA, Seo-Mayer P, Mariappan MR, Hodsdon $\mathrm{ME}$, Banasiak KJ, et al. Pediatric fatality following ingestion of dinitrophenol: postmortem identification of a "dietary supplement". Clinical Toxicology. 2005;43:281-285.

12. Ash-Bernal R, Wise R, Wright SM. Acquired methemoglobinemia. Medicine. 2004;83:265-273.

13. Saha S, Ghosh S. Tinospora cordifolia: One plant, many roles. Ancient science of life. 2012;31:151-159.

14. Choudhary N, Siddiqui M, Azmat S, Khatoon S. Tinospora cordifolia: ethnobotany, phytopharmacology and phytochemistry aspects. International Journal of Pharmaceutical Sciences and Research. 2013;4:891-899.

15. Upadhyay AK, Kumar K, Kumar A, Mishra HS. Tinospora cordifolia (Willd.) Hook. f. and Thoms.(Guduchi)-validation of the Ayurvedic pharmacology through experimental and clinical studies. International journal of Ayurveda research. 2010;1:112-121.

16. Vaghamshi R, Jaiswal M, Patgiri B, Prajapati P, Ravishankar B, Shukla V. A comparative pharmacological evaluation of Taila (oil) and Ghrita (ghee) prepared with Guduchi (Tinospora cordifolia). Ayu. 2010;31:504-508.

17. Stanely Mainzen Prince P, Menon VP. Antioxidant action of Tinospora cordifolia root extract in alloxan diabetic rats. Phytotherapy Research. 2001;15:213-218.

18. Patgiri B, Umretia BL, Vaishnav PU, Prajapati PK, Shukla VJ, Ravishankar B. Anti-inflammatory activity of Guduchi Ghana (aqueous extract of Tinospora Cordifolia Miers.). Ayu. 2014;35:108110.

19. Sharma A, Singh R. Screening of anti-inflammatory activity of certain indigenous drugs on carrageenin induced hind paw oedema in rats. Bulletin of Medico-Ethno-Botanical Research. 1981; 1:262-271.

20. Wesley J, Christina A, Chidambaranathan $\mathrm{N}$, Livingston $\mathrm{R}$, Ravikumar K. Effect of alcoho; ic extract of Tinospora cordifolia on acute and subacute inflammation. Pharmacologyonline. 2008; 3:683687.

21. Pendse V, Dadhich A, Mathur P, Bal M, Madan B. Antiinflammatory, immunosuppressive and some related pharmacological actions of the water extract of Neem Giloe (Tinospora cordifolia): A preliminary report. Indian journal of pharmacology. 1977; 9: 221-224.

22. Utpalendu J, Chattopadhyay RN, Badri PS. Preliminary studies on anti-inflammatory activity of Zingiber officinale Rosc., Vitex negundo Linn and Tinospora cordifolia (willid) Miers in albino rats. Indian journal of pharmacology. 1999;31:232-233.

23. Tiwari M, Dwivedi U, Kakkar P. Tinospora cordifolia extract modulates COX-2, iNOS, ICAM-1, pro-inflammatory cytokines and redox status in murine model of asthma. Journal of ethnopharmacology. 2014;153:326-337.

24. Pushp P, Sharma N, Joseph G, Singh R. Antioxidant activity and detection of $(-)$ epicatechin in the methanolic extract of stem of Tinospora cordifolia. Journal of food science and technology. 2013;50:567-572.

25. Pulido R, Bravo L, Saura-Calixto F. Antioxidant activity of dietary polyphenols as determined by a modified ferric reducing/antioxidant power assay. Journal of agricultural and food chemistry. 2000;48:3396-3402.

26. Re R, Pellegrini N, Proteggente A, Pannala A, Yang M, Rice-Evans C. Antioxidant activity applying an improved ABTS radical cation decolorization assay. Free radical biology and medicine. 1999;26:1231-1237.

27. Santhosh MS, Sundaram MS, Sunitha K, Kemparaju K, Girish K. Viper venom-induced oxidative stress and activation of inflammatory cytokines: a therapeutic approach for overlooked issues of snakebite management. Inflammation Research. 2013;62:721-731.

28. Driver AS, Kodavanti PRS, Mundy WR. Age-related changes in reactive oxygen species production in rat brain homogenates. Neurotoxicology and teratology. 2000;22:175-181.

29. Barja G. Minireview: the quantitative measurement of $\mathrm{H} 2 \mathrm{O} 2$ generation in isolated mitochondria. Journal of bioenergetics and biomembranes. 2002;34:227-233.
30. Ohkawa H, Ohishi N, Yagi K. Assay for lipid peroxides in animal tissues by thiobarbituric acid reaction. Analytical biochemistry. 1979;95:351-358.

31. Chandrashekar K. d-Aspartic acid induced oxidative stress and mitochondrial dysfunctions in testis of prepubertal rats. Amino acids. 2010;38:817-827.

32. Aebi H. Catalase in vitro. Methods in enzymology. 1984;105:121126.

33. Tenniswood M, Bird C, Clark A. Acid phosphatases: androgen dependent markers of rat prostate. Canadian journal of biochemistry. 1976;54:350-357.

34. Walter K, Schutt C. Alkaline phosphatase in serum. Methods of enzymatic analysis. 1974;2:860-864.

35. Lowry $\mathrm{OH}$, Rosebrough NJ, Farr AL, Randall RJ. Protein measurement with the Folin phenol reagent. J biol Chem. 1951;193:265-275.

36. Nur E, Biemond BJ, Otten HM, Brandjes DP, Schnog JJB. Oxidative stress in sickle cell disease; pathophysiology and potential implications for disease management. American journal of hematology. 2011;86:484-489.

37. Iuchi Y. Anemia caused by oxidative stress: INTECH Open Access Publisher; 2012.

38. Rana S. Free radical scavenging and metal chelation by Tinospora cordifolia, a possible role in radioprotection. Indian journal of experimental biology. 2002;40:727-734.

39. Daghman N, Elder G, Savage G, Winter P, Lappin T, Maxwell A. Erythropoietin production: evidence for multiple oxygen sensing pathways. Annals of hematology. 1999;78:275-278.

40. Zierle J, Bissinger R, Egler J, Lang F. Lapatinib Induced Suicidal Death of Human Erythrocytes. Cellular Physiology and Biochemistry. 2015;37:2275-2287.

41. Blokhina O, Virolainen E, Fagerstedt KV. Antioxidants, oxidative damage and oxygen deprivation stress: a review. Annals of botany. 2003;91:179-194.

42. Kelso GF, Porteous CM, Coulter CV, Hughes G, Porteous WK, Ledgerwood EC, et al. Selective targeting of a redox-active ubiquinone to mitochondria within cells antioxidant and antiapoptotic properties. Journal of Biological Chemistry. 2001;276:4588-4596.

43. Han YW, Kim SZ, Kim SH, Park WH. The changes of intracellular $\mathrm{H} 2 \mathrm{O} 2$ are an important factor maintaining mitochondria membrane potential of antimycin A-treated As4. 1 juxtaglomerular cells. Biochemical pharmacology. 2007;73:863-872.

44. Park WH, Han YW, Kim SH, Kim SZ. An ROS generator, antimycin A, inhibits the growth of HeLa cells via apoptosis. Journal of cellular biochemistry. 2007;102:98-109.

45. Stanely P, Prince M, Menon VP. Hypoglycaemic and other related actions of Tinospora cordifolia roots in alloxan-induced diabetic rats. Journal of ethnopharmacology. 2000;70:9-15.

46. Prince P, Kamalakkannan N, Menon VP. Restoration of antioxidants by ethanolic Tinospora cordifolia in alloxan-induced diabetic Wistar rats. Acta Pol Pharm. 2004;61:283-287.

47. Umamaheswari S, Prince PSM. Antihyperglycaemic effect of 'ilogenexcel', an ayurvedic herbal formulation in streptozotocin-induced diabetes mellitus. Acta Poloniae Pharmaceutica. 2007;64: 53-61.

48. Sharma V, Pandey D. Protective role of Tinospora cordifolia against lead-induced hepatotoxicity. Toxicology international. 2010;17:1217.

\section{How to cite this article:}

Rashmi KC, Aparna HS. DNP induced oxidative stress on blood components ameliorated by Pyrrole derivative of Tinospora cordifolia. J App Biol Biotech. 2017; 5 (01): 059065. DOI: 10.7324/JABB.2017.50110 